\title{
Migrant Workers for the Development of Industrial Zones in Bac Ninh Province, Vietnam
}

\author{
Ngo Trung Thanh ${ }^{1,2}$, Philippe Lebailly ${ }^{1} \&$ Nguyen Thi Dien ${ }^{2}$ \\ ${ }^{1}$ Department of Rural Economic, Gembloux Agro-Biotech, University Liege, Gembloux, Belgium \\ ${ }^{2}$ Department of Sociology, Vietnam National University of Agriculture, Hanoi, Vietnam \\ Correspondence: Ngo Trung Thanh, Gembloux Agro-Biotech, University of Liege, Gembloux 5030, Belgium. \\ E-mail: gzhivago@gmail.com
}

Received: October 21, 2018

doi:10.5539/ass.v14n12p115
Accepted: November 9, $2018 \quad$ Online Published: November 29, 2018

URL: https://doi.org/10.5539/ass.v14n12p115

\begin{abstract}
It is no doubt that industrial zones leverage economic development in many countries. However, migrant workers who are main labor forces in industrial zones faced to some vulnerable situations easily related to both working and non-working environment. Base on the survey of 190 migrant workers in two industrial zones in Bac Ninh, this study found that labor sustainability is threaten by going on the foot loose of traditional development of industrial zones. Migrant workers in these zones faced a trade-off between accepting a hard life and accumulating capitals as well as experiences for an expected better one afterward. They are going to be circular and leave these zones after staying several years on their works.
\end{abstract}

Keywords: migrant worker, industrial zone, working, non-working environment, trade-off

\section{Introduction}

\subsection{Introduce the Problem}

In development process of many countries in the world, migration takes place inevitably and it changes along the development of society. Many studies have shown that labor migration positively affects the well-being of displaced households (Fukase, 2013; Ngoma \& Ismail, 2013; Sikder \& Ballis, 2013; Zeitlyn et al., 2014). Similarly, Mohanty, Mohapatra et al. (2015) who demonstrated that the level, depth, and severity of poverty among migrant households was lower than those among non-migrant households. Migrants who migrated out had higher income per capital and better education in comparison with non-migrants (Vakulabharanam \& Thakurata, 2014). Conventionally, those migrations have been mentioned to urban settings or cities where development was higher than that of sending areas. Since industrial zones (named as exported processing zones) were bloomed, they were added as places that attracted migrant workers from rural areas (Sivananthiran, 2007; Lindgren Cortés, 2014).

It is no doubt that industrial zones leverage economic development in many countries (Farole and Akinci 2011). However, migrant workers in industrial zones who were typically young and female staying away from home may be easily vulnerable because of working as well as non-working environment. In fact, it did happen in some other developing countries that female migrant workers restrained to participate in family affairs because of long working schedule as well as distance from home (Wang et al., 2011). Even, many of them reported to lose their societal and community empowerment because of working in industrial zones (Hancock, 2009). Many migrant workers have not signed a formal contracts, even works in unmanaged environments at low wages (Frantz 2013, Pardis 2013). In addition, due to the nature of the work, migrant workers in factories face to physical inactivity illnesses (Liu et al., 2015) or mental illnesses (He \& Wong, 2013). In some cases, migrant workers also face sexual harassment (Puri \& Cleland, 2007) and have limited access to social services at the destination (Cortés, 2014; Ayre \& Khalifeh, 2017). More importantly, according to Farole and Akinci (2011) industrial zones exposed its limitation increasingly as an instrument of development. Low cost labors, as the most comparative advantage of industrial zones, will no longer be a sustainable resource.

\subsection{Explore Importance of the Problem}

Since "doi moi" (renovation), the transition to the market economy in Vietnam has created favorable conditions for labor mobilization in various forms (Anh, 2005). Especially, when the formation and development of 
industrial zones took place in most of the provinces in during the last 20 years, labor migration has been bloomed. According to UNIDO (2015) of the 2.3 million workers working in industrial zones, up to $70 \%$ of migrant workers. However, the mass national surveys of migration in 1999, 2009 and 2015 or migration studies do not target this group of migrants as an objective of research. As a result, current studies on the living and working conditions of migrant workers often refer to those who are in large cities or in informal employment sector (Oxfam, 2015; UNIDO, 2015).

Therefore, this study aims to understand labor sustainability in industrial zones through which the model of industrial zone development will be analyzed by the characteristics of migrant workers in industrial zones in Bac Ninh. Then, the analysis turns to focus on both working and non-working environment of migrant workers to justify if they create an impact on their choices for future livelihood. By those discussions, this study will shed light on the potential movements of labors who have worked for enterprises in industrial zones of Vietnam. It is highly probability to state that most migrant workers are going to quit industrial zones to elsewhere, including to return home.

\subsection{Describe Relevant Scholarship}

Over the last three decades the development of special economic zones which are also called exported processing zones or industrial zones has created a large quantity of employments. However, additional jobs generated by the zones have not been well documented since 2006 (Cirera et al., 2014). Literature review also shows that almost all workers are originated from rural areas; however, the proportion of migrant workers differs from country to country. It is estimated that around $20 \%$ of migrant workers were in the industrial zones of India (Aggarwal, 2007) and more than 90\% in Sri Lanka (Shaw, 2007).

In terms of gender, the evidence shows that most of migrant workers were female in many developing countries (Thanh, 2010; Cirera et al., 2014). In fact, industrial zones including light industries such as food processing, garment and textile, electrical appliance and components, metal product, optical instrument, and toys and crafts manufacturing and assembling activities require unskilled labors (Rondinelli, 1987; Thanh, 2009; McCallum, 2011). So, the work is more relevant to female than male workers. However, the proportion of female labor in industrial zones has declined over time. This might be related to changes in technology, the industrial composition of firms (labor-intensive to capital-intensive; light to heavy industries and wages (Kusago \& Tzannatos, 1998; Cirera et al., 2014).

Wage inside industrial zones is different among countries and it defers from outside industrial zones. In India, the study of Sen and Dasgupta (2008) showed that workers in industrial zones received relatively low wages compared to those have worked outside.. In Taiwan, Mauritius and Nicaragua wages inside the industrial zones are lower than those outside the zones. However, in China, Thailand, Sri Lanka, Honduras, and South Africa, wages are higher (Kusago \& Tzannatos, 1998; McCallum, 2011). In the case of Madagascar, Glick and Roubaud (2006) illustrated that wage inside industrial zones was higher that of informal sectors, but lower than that of other sectors outside the zones. In some countries like the Republic of Korea, Malaysia, and Bangladesh, wages in EPZs were initially lower than in non-EPZs but become higher after some point in time (Kusago \& Tzannatos 1998; Ahmed \& Nathan, 2014).

In fact, wages do not necessarily reveal the actual status of the work of a labor. Working conditions in industrial zones have never been evaluated positively since the early days of the industry. Consequently, working hours inside these zones are longer than that outside. Furthermore, discrimination exists between male and female workers on issues of pay equity and equal treatment. Even when the valid legislation exists, enforcement and accountability remain weak and laws are often unenforceable. It is also found that poor social respect and derogatory comments happened to workers in industrial zones (Hancock et al., 2015).

\subsection{State Hypotheses and Their Correspondence to Research Design}

According to neo-classical theory, traditional form of industrial zone, based on two sectors model of development, were established to attract foreign direct investments through which more employments as well as economic values were expected (Cling \& Letilly, 2001; Farole \& Akinci, 2011). This model of industrial zones presented a majority of light industries with low skilled and intensive labors (Aggarwal, 2007). In this point of view, the establishment of industrial zones contributed to well-being of host countries as mentioned by (Miyagiwa, 1986). However, the debates of industrial zone's impacts are still prolonged when Gupta (1994) and Cling and Letilly (2001) rose augments that those zones created higher proportion of unemployment, reduced national incomes, and were challenged by globalization process. However, it was likely that external effects of industrial zones that were ignored by classical theory has been paid more attention by new growth theories. According to (Farole \& Akinci, 2011), traditional model of industrial zone step by step had been changed toward 
new model that focused more on the links between industrial zones to local economies. Besides employment provision, these zones transferred knowledge and technology that enable local enterprises upgrading their capacity (Zhao \& Farole, 2011). By this way, industrial zones played a truly role that leveraged development of host countries. Following above theoretical discussions, the hypotheses of this study are formulated as:

H1: Industrial zones in Bac Ninh currently follows traditional model of development that relies on unskilled and intensive labors

H2: Migrant workers who work at industrial zones in Bac Ninh are challenged by both working environment provided by those zones and non-working environment surround for their livings.

H3: Migration to industrial zones of Bac Ninh is temporary rather than permanent.

\section{Method}

Bac Ninh, the study site, is the smallest province with 822.8 square kilometers where more than 1.2 million habitants resided, but it is ranked as the first of the number of emigrants in the North of Vietnam (GSO, 2017). Since early 2000s Bac Ninh started establishing an industrial zone for its economic development. Till now, 16 industrial zones were formed with more than 17 billion USD investment from 32 countries around the world. Thank to those zones, this province moves toward industrialization goals of which industry share has contributed $76 \%$ of provincial GDP in 2016.

This study was based on a questionnaire survey of 190 migrant workers who have been working at two industrial zones in Bac Ninh, including 92 workers in Que Vo Industrial zone and 98 workers in Yen Phong industrial zone. These industrial zones have been selected for their highest proportion of migrant workers, accounting for $69.3 \%$ of 127,384 migrant workers in the whole industrial zones of Bac Ninh. This proportion is respectively $50.4 \%$ and 82.2\% in Que Vo and Yen Phong industrial zone. In addition, Que Vo industrial zone was put into operation in 2001 and currently it has 131 enterprises with diverted fields of production, while Yen Phong industrial zone has been in operation since 2005 and currently it has 56 enterprises.

The sample size was calculated according to the equation:

$$
n=\frac{N}{\left(1+N * e^{2}\right)}
$$

where $n=$ sample size; $N=$ total population (89.259 migrant workers); e = sample variance (assumed at 7\%).

For these parameters, $n=205$ was supposed to generate. However, after cleaning the data, 190 have been used for analysis.

\section{Results}

\subsection{Characteristics of Migrant Workers in Industrial Zones in Bac Ninh}

The survey showed that migrant workers in both industrial zones, Que Vo and Yen Phong were an average age of about 23 years and dominated by female, accounting for $80.43 \%$ and $74.49 \%$ respectively (Table 1 ). In addition, almost of migrant workers presented in the industrial zones as low skill labors. Although those migrant workers who have college and university level of education were found, they have just accounted for $17.77 \%$ of total respondents, and it was quite in common between Que Vo and Yen Phong industrial zones. In fact, these migrant workers failed to obtain an employment in the areas of origin or at a place outside industrial zones of Bac Ninh and entered the industrial zones without presenting their highest level of education.

Regarding to marital status of migrant workers working in industrial zones, this study found that almost migrant workers was single. However, in order to maintain the life while working in industrial zones, the married migrant workers had a difference strategy to organize their living. Some of them left spouses at home villages, others stayed together with spouses with a job in the same industrial zone or other zones nearby. However, married migrant workers in Que Vo seemed to leave their spouses home more than those who were in Yen Phong. The possible explanation for this finding is that the migrant workers' wage in Yen Phong was more reasonable than that was in Que Vo. Thus, after experimenting a work at the zone, married migrant workers have convinced their spouse arriving for a work.

Concerning to migrant worker's preoccupation, like some literatures this study demonstrated a larger proportion of those who did not have a job prior to the migration to industrial zones or moved from agriculture work at the areas of origin. However, these proportion in Que Vo deferred from Yen Phong. While the proportion of non-preoccupation in Que Vo was lower than that in Yen Phong, the proportion of agriculture preoccupation was higher (Table 1). In addition, the survey also showed the presence of non-farm preoccupation of migrant workers 
in industrial zones. This proportion was not so high, accounting for $10 \%$ of the total number of surveyed workers, but this alluded to fact that employments in industrial zones is not only attracted by agricultural labors in rural areas.

Table 1. Characteristic differences of migrant workers in Que Vo and Yen Phong industrial zones of Bac Ninh

\begin{tabular}{|c|c|c|c|c|c|}
\hline & & \multirow{2}{*}{ Unit } & Que Vo & Yen Phong & Total \\
\hline & & & $(\mathrm{N}=92)$ & $(\mathrm{N}=98)$ & $(\mathrm{N}=190)$ \\
\hline \multicolumn{2}{|r|}{ Age } & Year & 23.63 & 22.12 & 22.85 \\
\hline \multirow{2}{*}{ Gender } & Male & $\%$ & 19.57 & 25.51 & 22.63 \\
\hline & Female & $\%$ & 80.43 & 74.49 & 77.37 \\
\hline \multirow{5}{*}{ Marriage status } & Married - spouse at home village & $\%$ & 18.48 & 7.14 & 12.63 \\
\hline & Married - spouse at same IZ & $\%$ & 14.13 & 32.65 & 23.68 \\
\hline & Married - spouse at other IZs & $\%$ & 4.35 & 7.14 & 5.79 \\
\hline & Single & $\%$ & 60.87 & 53.06 & 56.84 \\
\hline & Divorced & $\%$ & 2.17 & 0.00 & 1.05 \\
\hline \multirow{3}{*}{ Preoccupation } & No occupation (high school student) & $\%$ & 55.43 & 74.49 & 65.26 \\
\hline & Agriculture & $\%$ & 32.61 & 17.35 & 24.74 \\
\hline & Non-agriculture & $\%$ & 11.96 & 8.16 & 10.00 \\
\hline \multirow{5}{*}{ Education level } & Primary school & $\%$ & 11.96 & 5.10 & 8.42 \\
\hline & High school & $\%$ & 69.57 & 73.47 & 71.58 \\
\hline & Vocational school & $\%$ & 01.09 & 4.08 & 2.63 \\
\hline & College & $\%$ & 15.22 & 7.14 & 11.05 \\
\hline & University & $\%$ & 2.17 & 10.20 & 6.32 \\
\hline
\end{tabular}

Source: Data collection

\subsection{Working Environment and Income of Migrant Workers in Industrial Zones in Bac Ninh}

Although both Que Vo and Yen Phong industrial zone have been established for 10 to 15 years, the working duration of migrant workers in was difference and inconsistent with the duration development of these industrial zones. It was found that migrant workers have worked 11 months on average in Que Vo and approximately 14 months in Yen Phong (Table 2). The survey also showed that trial the period of migrant workers in Yen Phong industrial zone was a bit higher than that was in Que Vo. However, it all lasted for no more than two months in both Yen Phong anh Que Vo.

Table 2. Migrants' work environment and income in industrial zones of Bac Ninh

\begin{tabular}{llccc}
\hline & Unit & $\begin{array}{c}\text { Que Vo } \\
(\mathrm{N}=92)\end{array}$ & $\begin{array}{c}\text { Yen Phong } \\
(\mathrm{N}=98)\end{array}$ & $\begin{array}{c}\text { Total } \\
(\mathrm{N}=190)\end{array}$ \\
\hline Working duration (at IZs) & Month & 11.10 & 13.93 & 12.55 \\
Trial period & Month & 1.27 & 1.90 & 1.58 \\
Working hour & Hours/day & 10.80 & 10.86 & 10.83 \\
Extra hour & Hours/day & 2.84 & 2.92 & 2.88 \\
Working day with extra hour & Days/month & 26.13 & 18.49 & 22.01 \\
Wage at trial period & Million VND & 3.13 & 3.74 & 3.43 \\
Suffer work pressure & $\%$ & 52.2 & 71.4 & 60.0 \\
Income & Million VND & 5.54 & 6.78 & 6.18 \\
Remittance sent per times & Million VND & 2.20 & 4.05 & 3.15 \\
Sending remittance frequency & Month & 6.39 & 6.07 & 6.22 \\
Comparing income to areas of origin & & & & \\
Lower & $\%$ & 3.3 & 0 & 1.6 \\
No difference & $\%$ & 19.6 & 1.0 & 10.0 \\
Higher & $\%$ & 77.1 & 99.0 & 88.4 \\
\hline
\end{tabular}

Note: $1 \mathrm{USD}=22.456 \mathrm{VND}$

Source: Data collection

This study also found that working environment in Que Vo and Yen Phong industrial zone was relatively high labored intensive. On average, migrant workers have work for approximately 11 hours per day, including 3 extra hours and it was not significant difference between Que Vo and Yen Phong industrial zones (Table 2). However, 
the number of extra working days per month in Que Vo industrial zone is higher it is in Yen Phong. The survey revealed that migrant workers in Que Vo had 26.13 working days per while those in Yen Phong had 18.49 days per month (Table 2). Thus, compared to the average working hours per week of whole country, that of migrant workers in Que Vo and Yen Phong was respectively 1.89 and 1.45 times higher (Note 1). Additionally, according to interviews, extra working hours brought migrant workers more income, however, it was likely an obligation rather than a choice. Owners of enterprises do not expect a deny for extra hours from migrant workers due to assembly production applied. If someone on the line is missed, it is difficult to find a replaced worker that might cause negative impacts on enterprise's business. Therefore, migrant workers were often required to write an application (showing that they were willing to do) for working extra hours in needed case. By asking directly migrant workers to evaluate their working environment, $60 \%$ of them reported a suffer from work, especially $71.4 \%$ was in Yen Phong industrial zone, a significance higher than that was in Que Vo (Table 2). Those points of view are consistent with Cirera and Lakshman (2017) who argued that extra hour was compulsory and working hour inside industrial zones was long and even longer that that was outside the zones sometime.

Regarding to migrant workers' income per month (including wages and extra hour earn), majority of migrant workers also stated that their earnings from industrial zones of Bac Ninh, at 6.18 million VND (Table 2), were higher than those from non-farm employment at the areas of origin (at the time of interview). However, there was a significant difference between Que Vo and Yen Phong industrial zone. Those who were in Que Vo earned less than those in Yen Phong, 5.54 million VND and 6.78 million VND respectively. However, comparing to average income of unskilled labors in the whole country at 4.22 million VND per month (Note 2), migrant workers' earning in Que Vo was 1.3 times higher and that in Yen Phong was 1.6 times higher. Additionally, wage difference was not realized by $19.6 \%$ in Que Vo, a significance higher than that in Yen Phong. In fact, migrant's worker's remittance that was 2.2 million VND in Que Vo and 4.05 VND in Yen Phong (Table 2) has been send home every six months per year. It likely illustrated that migrant worker's earnings was less importance to households at the areas of origin.

\subsection{Non-Working Environment}

Although migrant workers could satisfy with monthly cash earnings, their main dissatisfaction resulted from non-working environment with poor amenities of living conditions that was in line to the demonstrations of Shaw (2007) and Arunatilake (2012). As observed, except small part of them in Yen Phong industrial zone was stayed in dormitories where were considered as reasonable accommodation, the others were resided in rent rooms at the villages around the zones where the condition was reported to be worse than that was at home villages. It was common to find rent rooms from $9 \mathrm{~m}^{2}$ to $12 \mathrm{~m}^{2}$ with minimum temporary facilities shared by two to four unmarried migrant workers. Hardships were more realized by those who already got married with an infant. No way out of ordinary, in this case, the mother or mother in-law of wife has been asked to arrive for taking care children until she or he weaned.

As residing in other's land, other's hometown (đất khách, quê ngươi), perceived by almost interviewed migrant workers, minimum living requirements were adopted. According to the survey, migrant worker's basic living cost in both Que Vo and Yen Phong industrial zone was 2.8 million VND on average per month, accounting for about $45.3 \%$ of their total income (Table 3). Of which, the most part was spend for daily food and minor expenses (pocket money). However, it found that the monthly expense of female migrant workers was at 2.7 million VND, lower than that of male ones at 3.1 million VND.

Table 3. Migrant workers' monthly expenses in industrial zones of Bac Ninh

\begin{tabular}{|c|c|c|c|c|}
\hline Basic expenses & Unit & $\begin{array}{c}\text { Male } \\
(\mathrm{N}=43)\end{array}$ & $\begin{array}{c}\text { Female } \\
(\mathrm{N}=147)\end{array}$ & $\begin{array}{c}\text { Total } \\
(\mathrm{N}=190)\end{array}$ \\
\hline Rent room (electricity, internet included) & Million VND & 0.70 & 0.56 & 0.59 \\
\hline Phone recharge & Million VND & 0.22 & 0.16 & 0.17 \\
\hline Food & Million VND & 1.07 & 1.01 & 1.03 \\
\hline Pocket money & Million VND & 1.11 & 0.98 & 1.01 \\
\hline Total & Million VND & 3.11 & 2.71 & 2.80 \\
\hline
\end{tabular}

Note: $1 \mathrm{USD}=22.456 \mathrm{VND}$

Source: Data collection

Due to long working hours and shift working, migrant workers used most non-working time for a sleep, from 6 hours to 8 hours per day, relaxing activities took place on few rests of the time in working days. Indeed, those activities that have done daily seemed to be relied on internet and more virtual interactions than those that have done weekly and monthly, and there was no significant difference between male and female migrant workers. 
Thank to internet access availability in every villages where migrant workers resided, main daily online activities such as watching movies, listening to music, and reading news were conducted by their own phone. It was $51.2 \%, 69.8 \%, 55.8 \%$ respectively for male respondents and $38.1 \%, 66.0 \%, 36.7 \%$ respectively for female ones (Table 4). Daily interactive relaxing interests were alo found mainly on migrant workers' virtual social networks, especially the use of Facebook which accounted for more than $74 \%$ of both total male and female respondents. Meanwhile, migrant workers' face to face talks or meetings that accounted for $30.23 \%$ of total male respondents and $20.41 \%$ of total female ones took place more weekly than the others were. Karaoke (singing together) was preferred conducting monthly because it costed higher than the other activities were.

Table 4. Migrant workers' non-working activities in industrial zones of Bac Ninh

\begin{tabular}{lcccccc}
\hline \multirow{2}{*}{ Activities } & \multicolumn{3}{c}{ Male $(\mathrm{N}=43)$} & \multicolumn{3}{c}{ Female $(\mathrm{N}=137)$} \\
\cline { 2 - 7 } & $\begin{array}{c}\text { Daily } \\
(\%)\end{array}$ & $\begin{array}{c}\text { Weekly } \\
(\%)\end{array}$ & $\begin{array}{c}\text { Monthly } \\
(\%)\end{array}$ & $\begin{array}{c}\text { Daily } \\
(\%)\end{array}$ & $\begin{array}{c}\text { Weekly } \\
(\%)\end{array}$ & $\begin{array}{c}\text { Monthly } \\
(\%)\end{array}$ \\
\hline Watching online movies & 51.16 & 9.30 & 0.00 & 38.10 & 14.97 & 2.72 \\
Listening to online music & 69.77 & 6.98 & 0.00 & 65.99 & 7.48 & 2.04 \\
Reading online news & 55.81 & 2.33 & 0.00 & 36.73 & 8.16 & 3.40 \\
Using virtual social networks & 74.42 & 11.63 & 0.00 & 74.15 & 6.80 & 0.00 \\
Singing Karaoke & 0.00 & 16.28 & 34.88 & 0.00 & 7.48 & 30.61 \\
Doing face to face chats & 16.28 & 30.23 & 9.30 & 5.44 & 20.41 & 11.56 \\
\hline
\end{tabular}

Source: Data collection

\subsection{Migrant Workers' Choices for Future}

Although most interviewed migrant workers stated that earning from Bac Ninh Industrial zones was higher than non-farm earning was at the areas of origin, many of them wanted to move out of there or to make a return. The survey showed that $48.4 \%$ of total respondents planned to create or find a non-farm employment on their return, while $15.8 \%$ of them were reported to stop working as long as they wished and $7.4 \%$ of them desired to find another non-farm employment outside the zones (Table 5). Those perceived that current jobs did not require high skills, but physical health and fitness. As their age is increasingly, these jobs will no longer be suitable. On the other hand, some of the migrant workers also witnessed those aged from 35 to 40 years old who quitted their jobs in industrial zones. In addition, most interviewed migrant workers agreed on the dissatisfaction resulted from poor amenities. Those act as factors that are going to push migrant workers to return. By contrast, other factors that arise from migrant workers' areas of origin pull them back. For examples, unmarried female migrant workers desired more to get married to somebody who resides near their hometown to be able to take care of their parents after wedding. Married migrant workers will be motivated by their children who currently live with stayers at hometown. It is reported that when their children are growing up, more cares need to be given. That's the reason why a migrant worker stated: "I will work a few more years in the industrial zone to earn some more money while I am waiting for my children growing up a bit".

Table 5. Migrant workers' choices for future

\begin{tabular}{lcccc}
\hline & Unit & Male & Female & Total \\
$(\mathrm{N}=43)$ & $(\mathrm{N}=147)$ & $190)$ \\
Keep working at the zones & $\%$ & 27.9 & 12.9 & 16.3 \\
Stop working, but have no plan & $\%$ & 16.3 & 15.6 & 15.8 \\
Create or seek an employment at home villages & $\%$ & 41.9 & 50.3 & 48.4 \\
Find a further study or training & $\%$ & 4.7 & 14.3 & 12.1 \\
Seek non-farm employment, but not at home villages & $\%$ & 9.3 & 6.8 & 7.4 \\
Total & $\%$ & 100.0 & 100.0 & 100.0 \\
\hline
\end{tabular}

Source: Data collection

Finally, migrant workers' purpose before the migration might result in their detachment from industrial zones, especially those who migration motived by non-economic purposes. As surveyed, $17.4 \%$ of total respondents was reported that their aim of emigrating to Bac Ninh industrial zones was to accumulate experiences. It was true for unmarried migrant workers who have just graduated from high school before the migration took place. Some others, accounting for $10 \%$ of total respondents hid their motivation of return under the target of capital accumulation for a later start-up at the areas of origin. The probability to move out of industrial zones of those migrant workers will be truly high when their goals is going to be archived. In addition, those who have got 
higher educated level, but have been working as low skill labor also reported that their work in industrial zones was temporary. They did there while waiting for another one outside the zones that is probably more relevance for their educated skills.

\section{Conclusions}

The migrant workers, major labor force for industrial zones, now face to challenges created by the unstable model of development. Industrial zones provide a working environment that seems not totally fulfill a satisfaction of migrant workers. Additionally, non-working environment provide facilities that are inadequate for migrant workers' stable living while they are working at the zones. Therefore, migrant workers' propensity is leaving rather than staying on works at the zones of Bac Ninh.

According to this study, the sustainability of the development of industrial zones in Bac Ninh is threaten by following the foot loose that old one exposed in 1990s when the zones favored more to young and female labors with intensive working hours, as a study of Madani (1999). Those who were typically low skilled labors and created an advantage for industrial zones development was no longer sustained like it did in Honduras, the pioneer country running industrial zones as leverage for economic development (Farole \& Akinci 2011).

This study found that migrant workers in industrial zones in Bac Ninh faced a trade-off between accepting a hard life and accumulating capitals as well as experiences for an expected better one afterward. Most of migrant workers suffered from working environment because of long hours schedule and compulsory work while they were residing in places with minimum requirements for their living. Emigrating to industrial zones with a hope to change the better way of life differing from rural hometown, however, migrant workers failed to archive even a basic social service, except accessing to internets.

In addition, the migration that undertaken by migrant workers in industrial zones of Bac Ninh seems to be circular. Those zones function as a place for young rural labors to enter the nonfarm labor market rather than to provide them a long-term employment. The fact is that most migrant workers tend to return to their areas of origin or to move out of the zones after several years staying on their works.

Those arguments suggest that industrial zones should provide more trainings and knowledge to uphold their development process and increase innovation capacities of areas where industrial zones are located (White, 2011). Furthermore, both working and non-working environment should be improved by reinforcing the implementation of the Law of housing that already issued in 2014.

\section{References}

Aggarwal, A. (2007). Impact of Special Economic Zones on Employment, Poverty, and Human Development. Indian Council for Research on International Economic Relations New Delhi.

Ahmed, N., \& Nathan, D. (2014). Improving wages and working conditions in the Bangladeshi garment sector: The role of horizontal and vertical relations. Capturing the Gains.

Anh, Đ. N. (2005). Chiều cạnh giới của di cư lao động trong thời kỳ công nghiệp hóa hiện đại hóa đất nước. Tạp chí Xã hội học, 2(90).

Arunatilake, N. (2012). Precarious Work in Sri Lanka. American Behavioral Scientist, 57(4), 488-506. https://doi.org/10.1177/0002764212466246

Ayre, K., \& Khalifeh, H. (2017). Immigrant women and women with learning disabilities have complex mental health needs and service use in the perinatal period. Evidence Based Mental Health, 20(2), 55-57. https://doi.org/10.1136/eb-2017-102607

Cirera, X., Lakshman, R., \& Spratt, S. (2014). The impact of export processing zones on employment, wages and labour conditions in developing countries. 3ie Grantee Final Systematic Review.

Cirera, X., \& Lakshman, R. W. D. (2017). The impact of export processing zones on employment, wages and labour conditions in developing countries: Systematic review. Journal of Development Effectiveness, 9(3), 344-360. https://doi.org/10.1080/19439342.2017.1309448

Cling, J.-P., \& Letilly, G. (2001). Export Processing Zones: A threatened instrument for global economy insertion. DIAL, documento de trabajo, DT/2001/17.

Deshingkar, P., Zeitlyn, B., \& Holtom, B. (2014). Does migration for domestic work reduce poverty? A review of the literature and an agenda for research. Migrating out of Poverty RPC.

Farole, T., \& Akinci, G. (2011). Special economic zones: progress, emerging challenges, and future directions. World Bank Publications. 
Frantz, E. (2013). Jordan's Unfree Workforce: State-Sponsored Bonded Labour in the Arab Region. The Journal of Development Studies, 49(8), 1072-1087. https://doi.org/10.1080/00220388.2013.780042

Fukase, E. (2013). Foreign job opportunities and internal migration in Vietnam. Policy Research Working Paper Washington, DC, World Bank. WPS6420.

Glick, P., \& Roubaud, F. (2006). Export Processing Zone Expansion in Madagascar: What are the Labour Market and Gender Impacts? Journal of African Economies, 14(4), 722-756.

GSO. (2017). Statistical summary book of Vietnam. Statistical Publish House.

Gupta, M. R. (1994). Duty-free zone, unemployment, and welfare a note. Journal of Economics, 59(2), 217-236. https://doi.org/10.1007/BF01238970

Hancock, P. (2009). Gender, status and empowerment: A study among women who work in Sri Lanka's Export Processing Zones (EPZs). Journal of Developing Societies, 25(4), 393-420.

Hancock, P., Carastathis, G., Georgiou, J., \& Oliveira, M. (2015). Female workers in textile and garment sectors in Sri Lankan Export Processing Zones (EPZs): gender dimensions and working conditions. Sri Lanka Journal of Social Sciences, 38(1).

He, X., \& Wong, D. F. K. (2013). A comparison of female migrant workers' mental health in four cities in China. International Journal of Social Psychiatry, 59(2), 114-122.

Hu, H.-Y., Wang, W.-A., \& Farn, C.-K.(2011). An exploratory research of cross-strait direct flights effect expatriates turnover intention. The journal of human resource and adult learning, 7(2), 146.

Kusago, T., \& Tzannatos, Z. (1998). Export Processing Zones: A Review in Need of Update. Social Protection Group, Human Development Network, The World Bank.

Lindgren Cortés, K. (2014). The Obedient EPZ-Worker: A case study concerning female EPZ workers' barriers to empowerment in Sri Lanka.

Liu, J., Cheng, Y., Lau, J. T. F., Wu, A. M. S., Tse, V. W. S., \& Zhou, S. (2015). The Majority of the Migrant Factory Workers of the Light Industry in Shenzhen, China May Be Physically Inactive. PLoS ONE, 10, e0131734. https://doi.org/10.1371/journal.pone.0131734

Madani, D. (1999). A review of the role and impact of export processing zones. The World Bank.

McCallum, J. K. (2011). Export processing zones: Comparative data from China, Honduras, Nicaragua and South Africa, ILO. Working Paper No. 21.

Miyagiwa, K. F. (1986). A reconsideration of the welfare economics of a free-trade zone. Journal of International Economics, 21(3-4), 337-350. https://doi.org/10.1016/0022-1996(86)90045-0

Mohanty, S. K., Mohapatra, S. R., Kastor, A., Singh,, A., \& Mahapatra, B. (2015). Does Employment-Related Migration Reduce Poverty in India? Journal of International Migration and Integration, 1-24. https://doi.org/10.1007/s12134-015-0436-y

Ngoma, A. L., \& Ismail, N. W. (2013). Do migrant remittances promote human capital formation? Evidence from 89 developing countries. Migration and Development, 2(1), 106-116. https://doi.org/10.1080/21632324.2013.786883

Oxfam. (2015). Rào cản pháp luật và thực tiễn đối với người lao động di cu trong tiếp cận an sinh xã hội.Chuoong trình quyền lao động của Oxfam tại Việt Nam, NXB Hồng Đức.

Pardis, M. (2013). Gender, labour and the law: the nexus of domestic work, human trafficking and the informal economy in the United Arab Emirates. Global Networks, 13(4), 425-440. https://doi.org/10.1111/glob.12010

Puri, M., \& Cleland, J. (2007). Assessing the factors associated with sexual harassment among young female migrant workers in Nepal. Journal of interpersonal violence, 22(11), 1363-1381.

Rondinelli, D. A. (1987). Export Processing Zones and Economic Development in Asia: A Review and Reassessment of a Means of Promoting Growth and Jobs. American Journal of Economics and Sociology, 46(1), 89-105. https://doi.org/10.1111/j.1536-7150.1987.tb01766.x

Sen, S., \& Dasgupta, B. (2008). Labour under stress: Findings from a survey. Economic and Political Weekly, 43(3), 65-72.

Shaw, J. (2007). 'There is No Work in My Village' The Employment Decisions of Female Garment Workers in Sri Lanka's Export Processing Zones. Journal of developing societies, 23(1-2), 37-58. 
Sikder, M. J. U., \& Ballis, P. H. (2013). Remittances and life chances: a study of migrant households in rural Bangladesh. Migration and Development, 2(2), 261-285. https://doi.org/10.1080/21632324.2013.814322

Sivananthiran, A. (2007). Promoting decent work in export processing zones (EPZs) in Sri Lanka.

Thanh, N. T. (2009). Land loss for industrial zone and rural employment. Sciences and Development, 7(English N0 1.).

Thanh, N. T. (2010). Migration Labor in Industrial Zone and Rural Labor Market. A Case Study in Que Vo Industrial Zone, Bac Ninh Province. Understanding Policy and Practice: Studies of Livelihoods in Transition, Hue City, Hue Universtiy Publish House.

UNIDO. (2015). Industrial parks, special economics zones, eco industrial parks, innovation districts as strategies for industrial conpetitiveness. Economic zones in the Asean. UNIDO country office in Vietnam

Vakulabharanam, V., \& Thakurata, S. G. (2014). Why Do Migrants Do Better Than Non-Migrants At Destination? Migration, Class And Inequality Dynamics In India. The Singapore Economic Review, 59(1), 1450003.

White, J. (2011). Fostering innovation in developing economies through SEZs. Special Economic Zones, 183.

Zhao, M., \& Farole, T. (2011). Partnership Arrangements in the China-Singapore (Suzhou) Industrial Park: Lessons for Joint Economic Zone Development. Special economic zones, 101.

\section{Notes}

Note 1. Average working hours per worker per week (whole country) in 2016 is 44.9 hours (General statistic office, 2017). Employment report 2016. Statistical Public House, page 31.

Note 2. Average income of unskilled labors per month (whole country) is 4.22 million VND (General statistic office, 2017). Employment report 2016. Statistical Public House, page 28.

\section{Copyrights}

Copyright for this article is retained by the author(s), with first publication rights granted to the journal.

This is an open-access article distributed under the terms and conditions of the Creative Commons Attribution license (http://creativecommons.org/licenses/by/4.0/). 